\title{
Resistance of different maize varieties against flour beetles, Tribolium casteneum and Tribolium confusum (Coleoptera:Tenebrionidae)
}

\author{
Sabeeta Kumari*, Nasreen Memon, Mansoor Ali Shah and Bhojoo Mal \\ Department of Zoology, University of Sindh, Jamshoro, Sindh-Pakistan \\ *Corresponding author's email: sabitagenious@gmail.com \\ Citation \\ Sabeeta Kumari, Nasreen Memon, Mansoor Ali Shah and Bhojoo Mal. Resistance of different maize varieties \\ against flour beetles, Tribolium casteneum and Tribolium confusum (Coleoptera:Tenebrionidae). Pure and Applied \\ Biology. Vol. 6, Issue 3, pp1061-1070. http://dx.doi.org/10.19045/bspab.2017.600113
}

\begin{tabular}{llll}
\hline \hline Received: 11/04/2017 & Revised: 20/08/2017 & Accepted: 26/08/2017 & Online First: 28/08/2017
\end{tabular}

\section{Abstract}

Maize is an important cereal crop, which is cultivated in all countries of tropics and sub-tropics. In the world, it ranks $3^{\text {rd }}$ grown crop. In Pakistan, maize is the fourth largest cultivated crop after wheat, cotton and rice. It is observed that common flour beetles including the red flour beetle and confused flour beetle are causing severe damage upon the maize crop. We have chosen four maize varieties such as Kachan, Neelum, Popcorn and White maize, because of their great importance mostly used by humans as nutrient/ food. This study was carried out from September 2015 to February 2016. Flour beetles were introduced separately on above four maize varieties. Therefore, the research was carried out to know about the most resistant varieties of maize. During laboratory experiments, we took $100 \mathrm{~g}$ of each variety and reared under ambient conditions at $27^{\circ} \mathrm{C} \pm 5^{\circ} \mathrm{C}$ and $22 \pm 5^{\circ} \mathrm{C}, 60 \%-65 \%$ relative humidity and with photoperiod of 10 hour produce two generations of both flour beetles. The percentage of weight loss was taken as criteria for measuring the resistance of these varieties against both flour beetles. We compared susceptibility and resistance of both flour beetles on four varieties. It was observed that maximum weight loss occurs on Kachan variety by both flour beetles while minimum on Popcorn, 21.63gand 2.56g respectively. On the basis of grain weight loss and seed damage, Popcorn variety of maize was the most resistant variety to both species as compared to other varieties. The resistance of Popcorn variety was due to hardness of seed coat, rough seed coat and coloration. On the basis of present observation, it is assessed that by growing resistant varieties, infestation of maize by flour beetles can be controlled.

Keywords: Flour beetles; Maize varieties; Resistant variety; Weight loss

\section{Introduction}

Crop production is playing most important role in the economical system of Asia. It contributes about 22 percent in gross domestic product (GDP). It is providing services for Asian people from 45 and 60 percent especially in rural and urban areas of Pakistan. Now a day, it is playing significant role in agriculture, food protection and improvement of the industrial system [1]. 
Maize is an essential crop in terms of human, animal diet and using as raw material in starch, glucose, oils, and fodder industry [2]. Approximately, 60\% of corn is cultivated in the agriculture and $36 \%$ in rainfall regions of Pakistan as $3^{\text {rd }}$ significant cereal crop after wheat and rice. It is grown twice a year (short duration crop). As compared to other countries like Argentina (5650 kg ha-1), China (4570 kg ha-1), Canada $\left(6630 \mathrm{~kg} \mathrm{ha}^{-1}\right)$ and Italy producing average maize yield of $9530 \mathrm{~kg} \mathrm{ha-1}$ Pakistan grain cultivation of maize is very low [3]. Now a day, in Pakistan corn is grown as a fodder crop about an area of 9.39 million ha, while sum of fodder cultivation is 3.34 million tons with an average yield of $3264 \mathrm{~kg} \mathrm{ha}^{-1}$ [4]. Insectaries are the major source of grain damage in the cultivated areas and storage pantry [5]. Flour beetles, $T$. castaneum (Herbst) and T. confusum (J. duval) attack on a list of 100 pantry products such as flour, cereals, dried flowers, dried pet food meal, beans, spices, pasta, cake mix, chocolate, nuts, seeds, and even dried museum specimens etc [6-8]. Several Tribolium species, mainly $T$. castaneum and $T$. confusum, have been studied in the laboratories for many years. Previous literature commonly focused on many sciences such as population ecology and population genetics as well as studies including genetics, physiology nutrition, and behavior. Both species are also significant due to their susceptibility to increase insecticide resistance [9-11]. Tribolium species are the most important pest of wheat flour [12]. The T. castaneum and $T$. confusum live in the same atmosphere and fight for similar resources [13]. In rigorous susceptibility, insects cause wide damage in storage places because of its maximum reproductive ability [14]. Its enormous financial importance is due to its reproductive potential which causes loss in storage pantry through more feeding and heating of cereals, in larvae capacity to defend against malnourishment for up to 2 years as well as its capability to live on groceries with very low humidity content. $T$. castaneum and $T$. confusum are not recognized to increase disease but they may cause allergic reactions. These beetles can be able to reproduce whole the year in temperate areas [15].

Keeping in view, the importance of these problems, present research was conducted to discuss the comparative resistance of different maize varieties against both flour beetles by determining the influence of infestation on their growth and their ability to resistance caused by infestation of flour beetles, which could be utilized in developing maize varieties resistance against this pest in future.

\section{Materials and methods}

\section{Experimental site}

The present investigations were carried out in Research Laboratory of Entomology Department of Zoology, University of Sindh Jamshoro during September 2015 to February 2016. The study on the varietal resistance of maize varieties against both flour beetles was conducted in the Laboratory of Entomology. The materials and methods employed on this study are as follows:

\section{Collection of maize samples}

Grains (Samples) of infested and noninfected maize varieties such as Kachan, Neelum, White maize and Popcorn were procured from Tower Market, Fakir Jo Pirh and nearby go downs (Hyderabad). These Maize varieties were observed for resistance against $T$. castaneum and T.confusum.

\section{Rearing of insects and experimental procedure}

Maize samples were cleaned and freeze below $0^{\circ} \mathrm{C}$ for two weeks to eliminate potential field infestation from each variety. Insects reared in the laboratory for maize grain resistance study. After cleaning, 100g 
of each variety was taken in the plastic jars have $150 \mathrm{~g}$ capacity. The jars were covered with aerated muslin cloth and held tightly with rubber band. In each Jar 20 newly emerged adult of both flour beetle were introduced in the center of the jar for free choice of oviposition. All experiments were conducted under ambient conditions $27^{\circ} \mathrm{C} \pm 5^{\circ} \mathrm{C}, \quad 22 \pm 5^{\circ} \mathrm{C}$, and $60-65 \% \quad \mathrm{RH}$ checked by a thermo hygrometer and a photoperiod of ten hours. The maize samples with insects were reared for six months. Data was collected after the interval of fifteen days to observe the strength of seed damage by the $T$. castaneum and T.confusum.

Percentage weight losses were observed by the counted and weighed method implemented by Alanko et al. [15] and Walter [16].

Percent weight loss $=(\mathrm{Wu} \times \mathrm{Nd})-(\mathrm{Wd} \times \mathrm{Nu}) \times 100$

Where

$\mathrm{Wu} \times(\mathrm{Nd}+\mathrm{Nu})$

$\mathrm{Wu}=$ weight of undamaged grains

$\mathrm{Nu}=$ number of undamaged grains

$\mathrm{Wd}=$ weight of damaged grains

$\mathrm{Nd}=$ number of damaged grains

These samples were reweighed to determine weight loss. Weight loss was determined by subtracting the value of infested maize from that of the control. Extra powdery material was sieved out from infested samples and weighted with an electrical balance machine. Grains morphological measurements and characters of each variety were observed on the illustration basis. Also comparison of susceptibility and resistance observed caused by flour beetles.

\section{Results}

Experiment was conducted to determine the resistant maize varieties against both flour beetles. There were four varieties selected Kachan, Popcorn, Neelum, and White maize for the observation of resistance against flour beetles under ambient conditions from September 2015 to February 2016. The study was conducted to know the percentage of damage and to observe the most susceptible and most tolerant varieties against flour beetles. We have chosen four local useable varieties because they are source of protein, vitamins and carbohydrate. The results of comparative resistance experiment clearly revealed that varieties viz, Kachan variety was significantly most susceptible to both flour beetles while Popcorn variety was comparatively most resistant to flour beetles attack. It is observed that resistance of this variety can be due to the hardness of kernel which may reduce the process of oviposition in Popcorn variety. It was observed that maximum consumption occurred on Kachan variety while minimum on Popcorn, 21.63 gand $2.56 \mathrm{~g}$ respectively. Here we discussed all varieties one by one.

\section{Susceptibility on Neelum variety by flour beetles}

During present study it was observed that flour beetles were causing severe infestation on Neelum variety throughout the research duration. The result of the present study indicates the Neelum variety was affected to both flour beetles. The reason was the variation in temperature, humidity, seed length, and seed surface coloration (Table 1). It is observed that Neelum variety was more susceptible to both flour beetles as compared to other varieties (Table 6). It was also found that more weight loss $5.79 \mathrm{~g}$ and 6.71 occurs in the months of September 2015 and February 2016 under ambient conditions $27^{\circ} \mathrm{C} \pm 5^{\circ} \mathrm{C}, 22 \pm 5^{\circ} \mathrm{C}$, and $60-65 \%$ $\mathrm{RH}$. The total weight loss of Neelum variety from the month of September 2015 to February 2016 was 20.9g (Table 2 and Figure 1). The total mean weight loss was $3.48 \mathrm{~g}$ on this variety. 
Table 1. Morphological characteristic of the investigated maize varieties (colour and grain length (mm)

\begin{tabular}{|c|c|c|}
\hline Variety & Colour & Grain Length (mm) \\
\hline Kachan & Yellowish & $0.62 \pm 0.103$ \\
\hline Neelum & Yellowish & $0.8 \pm 0.051$ \\
\hline Popcorn & Yellowish & $0.82 \pm 0.0918$ \\
\hline White Maize & White & $1.03 \pm 0.115$ \\
\hline
\end{tabular}

Table 2. The Susceptibility on Neelum variety by both flour beetles (Tribolium casteneum and Tribolium confusum)

\begin{tabular}{|c|c|c|c|c|}
\hline Sr. No & Months & Weight loss (in grams) & $\begin{array}{c}\text { Temperature } \\
\left({ }^{\circ} \mathbf{C}\right)\end{array}$ & $\begin{array}{c}\text { Humidity } \\
(\mathbf{R H})\end{array}$ \\
\hline & & & \multicolumn{2}{|c|}{ Mean } \\
\hline 1 & Sep-15 & 5.79 & 30.25 & 62.24 \\
\hline 2 & Oct-15 & 2.4 & 21.58 & 54.36 \\
\hline 3 & Nov-15 & 2.35 & 24.15 & 44.095 \\
\hline 4 & Dec-15 & 1.65 & 18.20 & 49.6 \\
\hline 5 & Jan-16 & 2 & 18.9 & 59.285 \\
\hline 6 & Feb-16 & 6.71 & 29.83 & 41.335 \\
\hline $\begin{array}{c}\text { Total weight } \\
\text { loss }\end{array}$ & & $\mathbf{2 0 . 9 g}$ & & \\
\hline
\end{tabular}

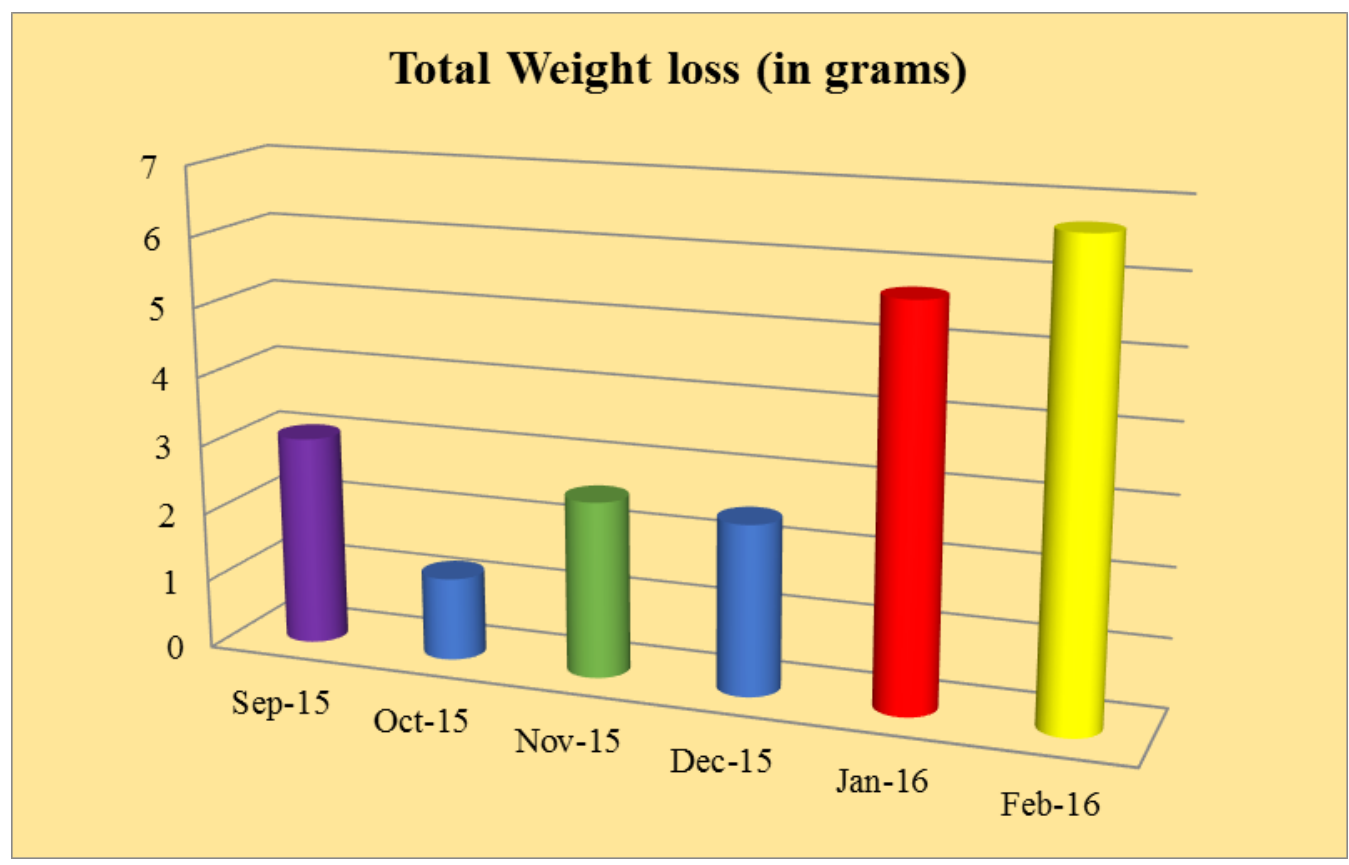

Figure 1. The susceptibility on Neelum variety by both flour beetles (September 2015 to February 2016) 
Susceptibility on Popcorn variety by both flour beetles

The results of present study revealed that Popcorn variety was the most resistant variety of maize (Table 6). It is observed that the resistance of this variance was due to the grain hardness and seed size, variation in temperature and relative humidity also thickness of Popcorn variety, which may affect the process of oviposition in Popcorn seeds coloration (Table 1). The present study showed that increasing hardness, size and thickness of seed resulted in reducing the susceptibility of Popcorn. Thus the total weight loss against flour beetles on this variety is $2.56 \mathrm{~g}$ (Table 3 and Figure 2). The total mean weight loss on this variety was $0.42 \mathrm{~g}$.

Table 3. The Susceptibility on Popcorn variety by both flour beetles (Tribolium casteneum and Tribolium confusum)

\begin{tabular}{|c|c|c|c|c|}
\hline Sr. No & Months & $\begin{array}{c}\text { Weight loss (in } \\
\text { grams) }\end{array}$ & $\begin{array}{c}\text { Temperature } \\
\left({ }^{\circ} \mathbf{C}\right)\end{array}$ & Humidity (RH) \\
\hline & & & \multicolumn{2}{|c|}{ Mean } \\
\hline 1 & Sep-15 & 0.15 & 30.25 & 62.24 \\
\hline 2 & Oct-15 & 0.5 & 21.58 & 54.36 \\
\hline 3 & Nov-15 & 0.15 & 24.15 & 44.095 \\
\hline 4 & Dec-15 & 0.7 & 18.20 & 49.6 \\
\hline 5 & Jan-16 & 0.8 & 18.9 & 59.285 \\
\hline 6 & Feb-16 & 0.26 & 29.83 & 41.335 \\
\hline Total weight loss & & $\mathbf{2 . 5 6 g}$ & & \\
\hline
\end{tabular}

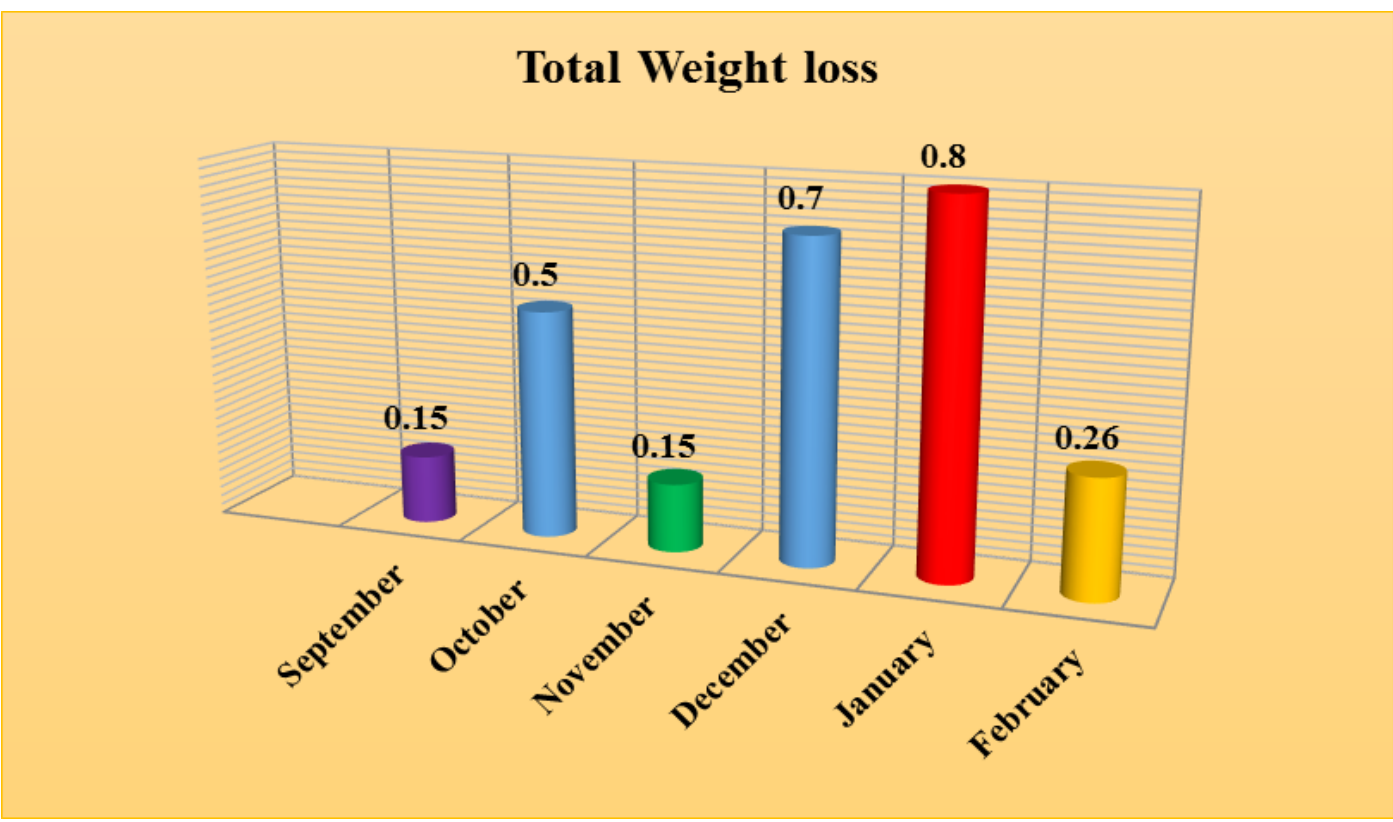

Figure 2. The Susceptibility on Popcorn variety by both flour beetles (September 2015 to February 2016) 
Susceptibility on Kachan variety by both flour beetles

The result of this experiment site indicates that Kachan variety was also more affected to flour beetles. The reason was same variation in temperature, humidity, seed size, and seed surface coloration (Table 1).It is observed that Kachan variety was most susceptible to flour beetles (Table 6). It is found that maximum weight loss $6.68 \mathrm{~g}$ occurs in the month of February 2016 under ambient conditions $27^{\circ} \mathrm{C} \pm 5^{\circ} \mathrm{C}, 22 \pm 5^{\circ} \mathrm{C}$, and $60-65 \% \mathrm{RH}$. The total weight loss from the month of September 2015 to February 2016 was 21.63g (Table 4 and Figure 3). The total mean weight loss on this variety was $3.60 \mathrm{~g}$.

Table 4. The susceptibility on Kachan variety by both flour beetles (Tribolium casteneum and Tribolium confusum)

\begin{tabular}{|c|c|c|c|c|}
\hline Sr. No & Months & $\begin{array}{l}\text { Weight loss (in } \\
\text { grams) }\end{array}$ & $\begin{array}{l}\text { Temperature } \\
\left({ }^{\circ} \mathrm{C}\right)\end{array}$ & Humidity (RH) \\
\hline & & & \multicolumn{2}{|l|}{ Mean } \\
\hline 1 & Sep-15 & $3.05 \mathrm{~g}$ & 30.25 & 62.24 \\
\hline 2 & Oct-15 & $1.2 \mathrm{~g}$ & 21.58 & 54.36 \\
\hline 3 & Nov-15 & $2.55 \mathrm{~g}$ & 24.15 & 44.095 \\
\hline 4 & Dec-15 & $2.46 \mathrm{~g}$ & 18.20 & 49.6 \\
\hline 5 & Jan-16 & $5.69 \mathrm{~g}$ & 18.9 & 59.285 \\
\hline 6 & Feb-16 & $6.68 \mathrm{~g}$ & 29.83 & 41.335 \\
\hline Total weight loss & & $21.63 \mathrm{~g}$ & & \\
\hline
\end{tabular}

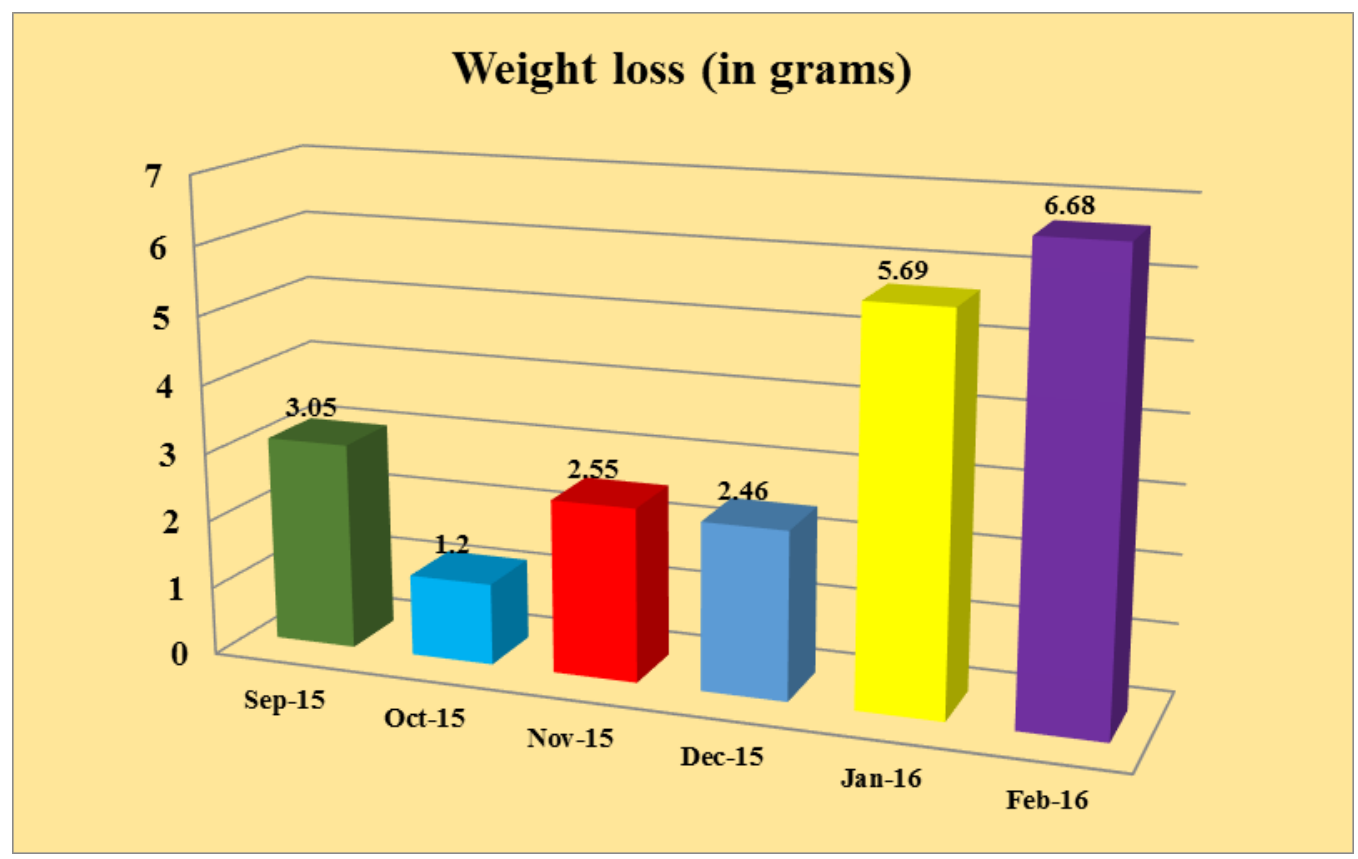

Figure 3. The susceptibility on Kachan variety by both flour beetles (September 2015 to February 2016) 
Susceptibility on White maize variety by both flour beetles

The result of the present study indicates that white maize variety was moderately resistant variety of maize (Table 6). It is observed that the resistance of this variance was due to the grain resistance and small seed size, difference in temperature and relative humidity also thickness of White maize, which may affect the process of oviposition in white maize seeds coloration (Table 1). The present study showed that increasing size and thickness of seed resulted in reducing the consumption or susceptibility of White maize (Table 5 and Figure 4). The total mean weight was $1.07 \mathrm{~g}$ on this variety.

Table 5. The susceptibility on white maize by both flour beetles (Tribolium casteneum and Tribolium confusum)

\begin{tabular}{|c|c|c|c|c|}
\hline Sr. No & Months & $\begin{array}{c}\text { Weight loss (in } \\
\text { grams) }\end{array}$ & $\begin{array}{c}\text { Temperature } \\
\left({ }^{\circ} \mathbf{C}\right)\end{array}$ & Humidity (RH) \\
\hline & & & \multicolumn{2}{|c|}{ Mean } \\
\hline 1 & Sep-15 & $1.05 \mathrm{~g}$ & 30.25 & 62.24 \\
\hline 2 & Oct-15 & $1.25 \mathrm{~g}$ & 21.58 & 54.36 \\
\hline 3 & Nov-15 & $1.15 \mathrm{~g}$ & 24.15 & 44.095 \\
\hline 4 & Dec-15 & $1.25 \mathrm{~g}$ & 18.20 & 49.6 \\
\hline 5 & Jan-16 & $0.22 \mathrm{~g}$ & 18.9 & 59.285 \\
\hline 6 & Feb-16 & $1.54 \mathrm{~g}$ & 29.83 & 41.335 \\
\hline Total weight loss & & $\mathbf{6 . 4 6 g}$ & & \\
\hline
\end{tabular}

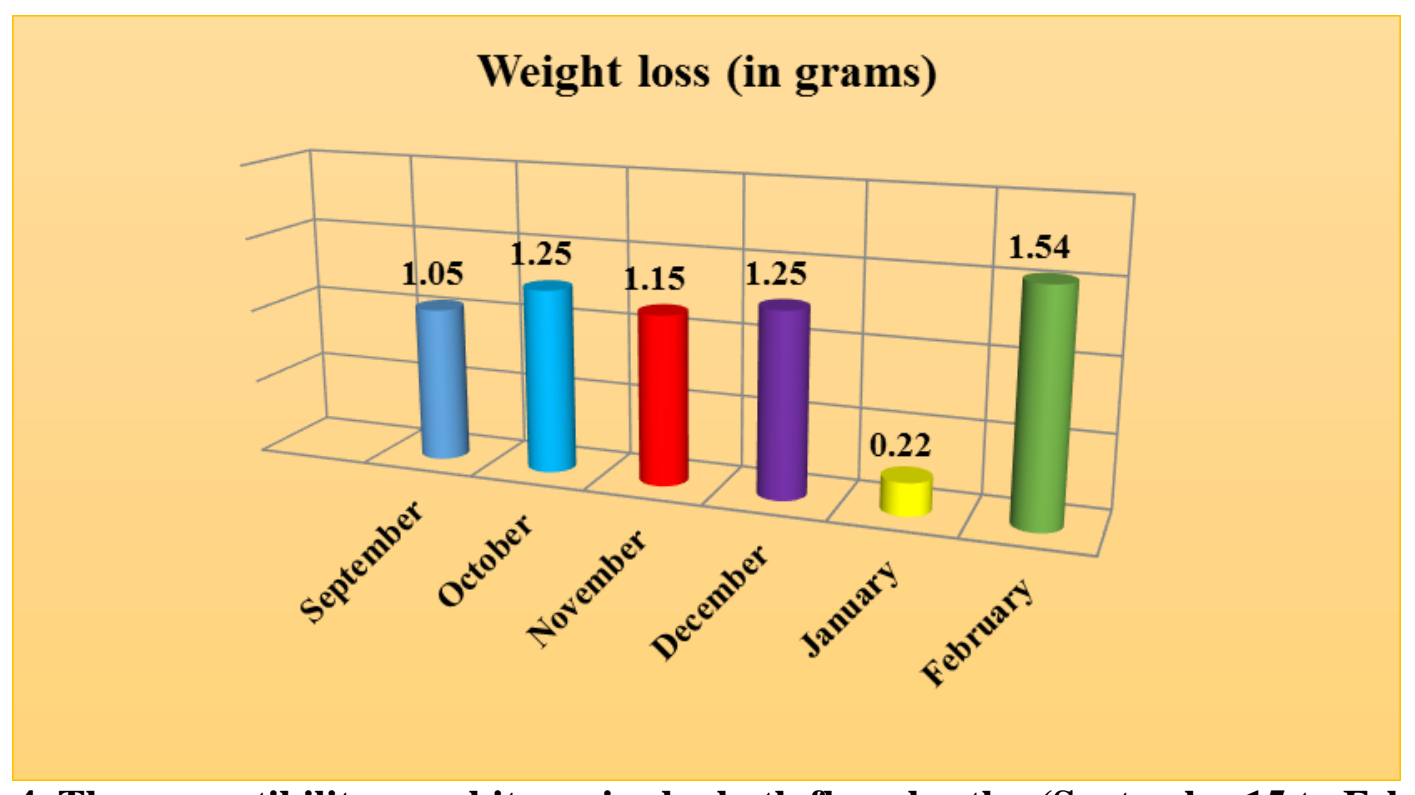

Figure 4. The susceptibility on white maize by both flour beetles (September15 to February 2016) 
Table 6. Comparison of resistance on different maize varieties by both flour beetles beetles (Tribolium casteneum and Tribolium confusum)

\begin{tabular}{|c|c|c|}
\hline Maize Varieties & \multicolumn{2}{|c|}{ Observations about nature of Resistance } \\
\hline & T. casteneum & T.confusum \\
\hline Popcorn & Most Resistant & Most Resistant \\
\hline White Maize & Moderately Resistant & Moderately Resistant \\
\hline Kachan & Most Susceptible & Most Susceptible \\
\hline Neelum & Susceptible & Susceptible \\
\hline
\end{tabular}

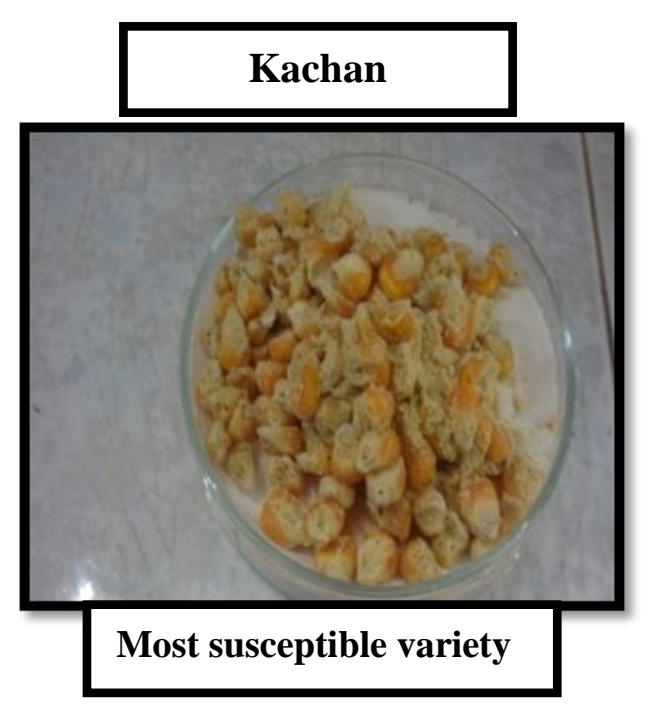

Discussion

In present study, it is observed that due to hardness or seed coat thickness there is least susceptibility on Popcorn variety. So for this reason Popcorn variety is the most resistant variety. These results were also agreed with $[17,18]$, they observed that the, resistance was due to hardness of seed coat and lack of feeding stimulus in the resistant kernels. The other researcher observed that high tolerance in cereal grains to pantry pests has been due to low adult progeny and low weight loss of grains $[19,20]$. It is observed that due to resistance/ hardness of seed coat, less growth rate and least weight loss occurred particularly on Popcorn variety from September 2015 to February 2016.

In many areas of Sindh (Pakistan), it is found that most of the damage/ susceptibility on stored products especially

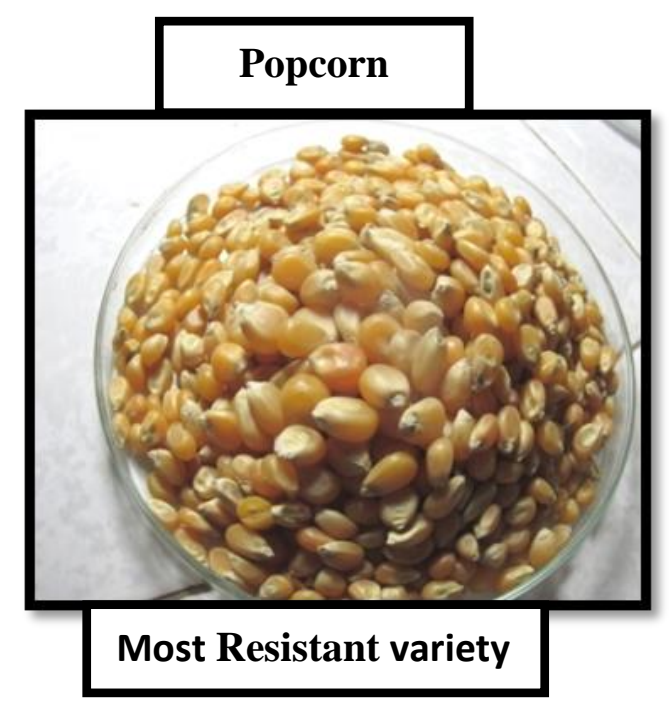

on maize varieties caused by flour beetles (Tribolium casteneum and Tribolium confusum), but our results were little bit varied with [21, 22] because in previous literature it was found that most of the economic damage on stored maize caused by maize weevil, and the larger grain borer (LGB), Prostephanus truncates, red flour beetle, Angoumois grain moth and the lesser grain weevil, and dried bean beetle etc. It is observed that both flour beetles $T$. casteneum and T.confusum compete for same habit and habitat.

Using susceptibility tables and comparing the results with that of the control varieties, Popcorn variety exhibited resistance and other varieties showed susceptibility to Red flour beetles and Confused flour beetles. This result was compared with [23] it was stated that moisture content over 16 percent 
renders resistant maize genotypes vulnerable. During storage condition moisture tends to increase within the cereal products and increase the moisture substances. This could describe the decrease in resistance on some of the varieties.

T. casteneum and T.confusum is found in huge numbers in contaminated grain, but is unable to attack pure grain. This result was comparable with [24] who also observed that both flour beetles are found in huge numbers in contaminated grain. The results clearly indicated that the adult progeny, feeding behavior and grain weight loss of maize varieties caused by Tribolium Spp individually as well as in combination varied significantly. It was also observed that under favorable condition the rate of consumption, weight loss, more oviposition, and fecundity was high on Kachan variety but least on Popcorn variety. The grain weight loss by flour beetles was likewise highest (21.63g) on kachan. Minimum grain weight loss was recorded on variety Popcorn was (2.56g). Finally it is observed that Popcorn maize variety is the most resistant among all four varieties.

\section{Conclusion}

The compiled results of comparative resistance experiments clearly demonstrated that varieties viz., Kachan variety was significantly susceptible to both flour beetles while Popcorn variety was comparatively resistant to both flour beetles attack. As the Popcorn variety showed the lowest percentage of weight loss, grain damage and no any adult population, it means that Popcorn variety was most resist and least susceptible variety as compared to other varieties. It was also observed that under favorable condition the rate of consumption, weight loss, seed damage, oviposition, and fecundity was high on Neelum and Kachan varieties. For the former varieties, when considering flour beetles management on stored products, more consideration and awareness should be directed towards those of cereals, with Kachan, Neelum and White Maize Varieties deserving the maximum care due to their highest susceptibility.

\section{Author's contributions}

Conceived and designed the experiments: $\mathrm{K}$ Sabeeta, N Memon \& MA Shah, Performed the experiments: K Sabeeta, Analyzed the data, K Sabeeta \& N Memon, Contributed reagents/ materials/ analysis tools: $\mathrm{K}$ Sabeeta \& A Attullah: Wrote the paper: K Sabeeta \& N Memon.

\section{References}

1. Anonymous (2011). Economic Survey of Pakistan. Economic Advisors wing, Finance Division, Islamabad, p. 17.

2. Kirtok Y (1998). Production and Using of Maize, Kocaoluk Press, Istanbul, Turkey.

3. Abuzar MR, Sadozai GU, Baloch MS, BalochAA, Shah IH, Javaid T \& Hussain $\mathrm{N}$ (2011). Effect of plant population densities on yield of maize. J Animal \& Plant Sci 21: 692-695.

4. Govt. of Pakistan (2011). Economic Survey of Pak, 2010-11. Finance Division, Economic Advisor's Wing, and Islamabad, Pakistan.

5. Suleiman R, Rosentrater K \& Bern C (2013). Effects of Deterioration Parameters on Storage of Maize: A Review. Journal of Natural Sciences Research 3(9): 147-165.

6. Weston PA \& Rattlingourd PL (2000). Progeny production by Tribolium castaneum (Coleoptera: Tenebrionidae) and Oryza ephilussurinamensis (Coleoptera: Silvanidae) on maize previously infested by Sitotrogacerealla (Lepidoptera: Gelechiidae) Journal of Economic Entomology 93:533-536.

7. Sokoloff A (1972). The biology of Tribolium with special emphasis on genetic aspects, Vol. 1. Clarendon Press and Oxford University Press, Oxford.

8. Sokoloff A (1974). The biology of Tribolium with special emphasis on 
genetic aspects, Vol. 2. Clarendon Press and Oxford University Press, Oxford.

9. Sokoloff A (1976). The biology of Tribolium with special emphasis on genetic aspects, Vol. 3. Clarendon Press and Oxford University Press, Oxford.

10. Tripathi AK, Prajapati V, Aggarwal KK \& Kumar S (2001). Toxicity, feeding deterrence, and effect of activity of 1,8 ,Cineole from Artemisia annua on progeny production of Tribolium castaneum (Coleoptera: Tenebrionidae). Journal of Economic Entomology 94: 979-983.

11. Karunakaran C, Jayas DS \& White NDG (2004). Identification of wheat kernels damaged by the red flour beetle using Xray image. Biosys Engin 87(3): 267-274.

12. Ryan MF, Park T \& Mertz DB (1970). Flour beetles responses to extracts of their own pupae. Science 170:178-180.

13. Prakash AJ, Rao IC, Pasalu \& Mathur KC (1987). Rice Storage and insect pests' management. BR Publishing Corporation, New Delhi, pp: 337.

14. William F Lyon (1991). Confused and Red flour Beetles. Extension Fact sheet, Entomology, Ohio State University.

15. Alanko K, Tuomi Y, Vanhanen M, Pajari-Backas M, Kanerval L, Havu K \& Bruynzeel DP (2000). Occupational IgEmediated allergy to Tribolium confusum (confused flour beetle) Allergy 55: 879882

16. Walter VE (1990). Stored product pests. In Handbook of Pest Control (Story K,
Moreland D (editors). Franzak \& Foster Co, Cleveland, OH. pp. 526-529.

17. Khattak SUK, Hamed M \& Khatoon R (1988). Relative susceptibility of different local maize varieties to $S$. cerealella. Pakistan J Zool 20: 137-142.

18. Li I \& Arbogast RT (1991). The effect of grain breakage on fecundity, development, survival and population increase in maize of Tribolium castaneum (Herbst) (Coleoptera: Tenebrionidae). $J$ Stored Prod Res 7: 87-94.

19. Suleiman R, Williams, D Nissen, A, Bern CJ \& Rosentrater KA (2015). Is flint corn naturally resistant to Sitophilus zeamais infestation? Journal of Stored Products Research 60: 19-24.

20. Gitonga Z, De Groote \& Tefera $T$ (2015). Metal silo grain storage technology and household food security in Kenya. Journal of Development and Agricultural Economics 7(6): 222-230.

21. Good NE (1936). The flour beetles of the genus Tribolium. UDSA Technical Bulletin No. 498, 1-57.

22. Ryan MF, Park T \& Mertz DB (1970). Flour beetles: responses to extracts of their own pupae. Science 170: 178-180.

23. Bergvinson DJ (1999-2000) Storage Pest Resistance in Maize programme Maize Research Highlights. CIMMYT, Mexico D. F., 32-39. (2001) Mexico.

24. Via S (1999). Cannibalism facilitates the use of a novel environment in the flour beetle, Tribolium castaneum. Heredity 82: 267-275. 